\title{
KARAKTERISTIK SOSIODEMOGRAFI, KLINIS, DAN POLA TERAPI ANTIRETROVIRAL PASIEN HIV/AIDS DI RSPI PROF. DR. SULIANTI SAROSO PERIODE JANUARI - JUNI 2016
}

\author{
CHARACTERISTICS OF SOCIODEMOGRAPHY, CLINICAL, AND PATTERN OF \\ ANTIRETROVIRAL THERAPY OF HIV/AIDS PATIENTS \\ AT RSPI PROF. DR. SULIANTI SAROSO IN THE PERIOD JANUARY TO JUNE 2016
}

\author{
Yelfi Anwar ${ }^{1}$, Sucahyo Adi Nugroho ${ }^{2}$, Niken Diaz Tantri ${ }^{1}$ \\ ${ }^{1}$ Program Studi Farmasi, Universitas 17 Agustus 1945, Jakarta \\ ${ }^{2}$ RSPI Prof. dr. Sulianti Saroso, Jakarta \\ Email: yelfi.anwar@uta45jakarta.ac.id (Yelfi Anwar)
}

\begin{abstract}
ABSTRAK
HIV/AIDS merupakan suatu penyakit yang disebabkan oleh infeksi human immunodeficiency virus. Penyakit ini mengganggu sistem kekebalan tubuh dengan menekan dan menurunkan jumlah sel CD4 sehingga meningkatkan risiko infeksi oportunistik yang dapat dicegah dengan adanya terapi antiretroviral. Penelitian ini bertujuan untuk mengetahui karakteristik sosiodemografi, klinis, dan pola terapi antiretroviral pada pasien HIV/AIDS di RSPI Prof. dr. Sulianti Saroso periode Januari-Juni 2016. Desain penelitian ini adalah deskriptif dengan penelusuran data bersifat retrospektif. Sampel dalam penelitian ini adalah 124 pasien HIV/AIDS yang mendapatkan terapi antiretroviral di klinik Pokja HIV/AIDS dalam kurun waktu Januari hingga Juni 2016, data diambil dari rekam medis. Hasil penelitian menunjukkan pasien HIV/AIDS didominasi oleh laki-laki (74,19\%) usia 30-39 tahun (40,32\%) dengan jumlah CD4 terbanyak di bawah $200 \mathrm{sel} / \mu \mathrm{l}$ (59,29\%) dengan stadium I (44,35\%) disertai infeksi kandidiasis $(17,74 \%)$, dimana pola terapi lini I yang digunakan adalah Tenofovir + Lamivudine + Evafirens $(65,23 \%)$ dengan kepatuhan pasien $75 \%$. Diharapkan penelitian ini dapat bermanfaat untuk perumusan program pencegahan dan tatalaksana HIV/AIDS di masa mendatang.
\end{abstract}

Kata kunci: HIV/AIDS, karakteristik sosiodemografi, karakteristik klinis, karakteristik pola terapi antiretroviral.

\begin{abstract}
HIV/AIDS is a disease caused by human immunodeficiency virus infection. It disease disrupts the immune system by suppressing and lowering CD4 cell count and then increases the risk of opportunistic infections that can be prevented by using antiretroviral therapy. This study aims to find out characteristics of sociodemography, clinical, and pattern of antiretroviral therapy of HIV/AIDS patients in RSPI Prof. dr. Sulianti Saroso during January - June 2016. The research was a descriptive retrospective study. The samples in this study were 124 patients with HIV/AIDS who received antiretroviral
\end{abstract}


therapy at RSPI Prof. dr. Sulianti Saroso in the period January - June 2016, data was retrieved from medical records. The results showed patients with HIV/AIDS are mainly men (74.19\%), age 30-39 years old (40.32\%) mostly with CD4 cell counts below 200 cells/ $\mu$ I (59.29\%) within stage I (44.35\%) accompanied by candidiasis infection (17.74\%), wherein the pattern of first-line therapy used is Tenofovir + Lamivudine + Evafirens (65.23\%) with $75 \%$ patients adherence. This study is expected to be useful for the formulation of prevention and treatment of HIV/AIDS in the future.

Key words: HIV/AIDS, characteristic sociodemography, characteristic clinical, characteristic pattern of antiretroviral therapy. 


\section{Pendahuluan}

HIV (Human Immunodeficiency

Virus) adalah virus yang menyerang sistem kekebalan tubuh manusia, sedangkan AIDS (Acquired Immunodeficiency Syndrome) adalah sindrom kekebalan tubuh oleh infeksi HIV. Virus masuk melalui perantara darah, semen, dan sekret vagina. Sebagian besar penularan (75\%) diakibatkan hubungan seksual. (Noviana, 2016).

$$
\text { Di dunia, AIDS pertama kali }
$$

dikenal sebagai gejala entitas klinis yang aneh pada tahun 1981, secara retrospektif dapat dilacak kembali bahwa kasus AIDS telah muncul selama tahun 1970-an di AS dan di beberapa bagian di dunia (Kunoll, 2013). WHO memperkirakan lebih dari 13 juta kasus dan sekitar $2 / 3$ nya di negara subSahara Afrika. Di Asia dan Pasifik, diperkirakan sekitar 4,8 juta orang yang hidup dengan HIV pada tahun 2013 termasuk 350.000 orang terinfeksi HIV baru (Najmah, 2016).

Laporan Situasi Perkembangan HIV \& AIDS di Indonesia sampai dengan Juni 2016 tercatat jumlah infeksi HIV yang dilaporkan sebanyak 17.847 kasus, dengan rasio laki-laki dan perempuan $2: 1$, dan persentase tertinggi pada kelompok usia 25-49 tahun. Sedangkan kasus AIDS sampai dengan Juni 2016, jumlah AIDS yang dilaporkan baru sebanyak 3.267 orang dengan rasio lakilaki dan perempuan 2:1, dan persentase tertinggi pada kelompok usia 30-39 tahun (Ditjen P2P, 2016). Dari informasi tersebut dapat dikatakan bahwa ada kasus baru HIV/AIDS tiap tahunnya.

$$
\text { Pengidap HIV memerlukan }
$$

Antiretroviral (ARV) untuk menurunkan jumlah HIV dalam tubuh agar tidak berlanjut ke stadium AIDS. Terapi ARV mencegah terjadinya infeksi oportunistik dengan berbagai komplikasinya (Ditjen P2PL, 2011). Sehingga penting bagi penderita HIV/AIDS mematuhi terapi ARV untuk menekan perkembangan virus dan hidup normal lebih lama.

Hasil dari penelitian oleh Fajrin (2012) di Unit Pelayanan Terpadu HIV RSUPN Dr. Cipto Mangunkusumo tahun 2009 pada pasien HIV/AIDS yang mendapatkan terapi ARV, pasien mengalami peningkatan jumlah CD4 maupun berat badan. Adanya penelitian di RSPI Prof. dr. Sulianti Saroso Jakarta oleh Lubis (2010) diketahui karakteristik pasien HIV/AIDS paling banyak pada usia 30-39 tahun yang didominasi oleh 
laki-laki, dengan nilai CD4 terbanyak $<200$ serta stadium terbanyak adalah stadium 3, dimana frekuensi tertinggi infeksi oportunistiknya adalah tuberkulosis. Dari penelitian tersebut peneliti ingin melihat karakteristik pasien selain sosiodemografi dan klinis juga melihat karakteristik pola terapinya.

RSPI Prof. dr. Sulianti Saroso, Jakarta, dipilih karena rumah sakit tersebut merupakan salah satu rumah sakit rujukan pasien HIV/AIDS di daerah Jakarta Utara. Data Ditjen P2P pada tahun 2013 di RSPI Prof. dr. Sulianti Saroso terdapat 395 jumlah kunjungan. Tahun 2014 terdapat 272 kunjungan dan pada tahun 2015 berjumlah 204 kunjungan. Dari alasanalasan tersebut, peneliti tertarik untuk melakukan penelitian tentang karakteristik sosiodemografi, klinis, dan pola terapi antiretroviral pasien HIV/AIDS di RSPI Prof. dr. Sulianti Saroso.

\section{Metode Penelitian}

Penelitian ini merupakan penelitian deskriptif melalui penelusuran data yang bersifat retrospektif terhadap data rekam medis pasien HIV/AIDS yang menjalani pengobatan ARV di RSPI Prof. dr. Sulianti Saroso, Jakarta, selama kurun waktu Januari hingga Juni tahun 2016. Sampelnya adalah semua pasien lakilaki dan perempuan dari semua umur yang terdaftar di RSPI Prof. dr. Sulianti Saroso, Jakarta dan diberi terapi ARV selama kurun waktu Januari hingga Juni 2016.

Variabel pada penelitian ini adalah umur, jenis kelamin, tingkat pendidikan, pekerjaan, status pernikahan, dan daerah tempat tinggal pada karakteristik sosiodemografi, jumlah CD4, stadium klinis, dan infeksi oportunistik pada karakteristik klinis, dan karakteristik golongan terapi ARV, jenis terapi ARV, dan kepatuhan terapi ARV pada pola terapi pasien HIV/AIDS berdasarkan data catatan rekam medis pada tahun 2016.

Data yang dikumpulkan pada penelitian ini adalah data yang bersumber dari buku rekam medis pasien HIV/AIDS yang menjalani terapi ARV di RSPI Prof. dr. Sulianti Saroso selama kurun waktu Januari hingga Juni 2016. Data yang telah dikelompokkan kemudian dianalisis univariat. Data yang relevan akan disajikan dalam bentuk tabel persentasi dan frekuensi. 


\section{Hasil dan Pembahasan}

Dari hasil penelitian yang dilakukan dari bulan Februari hingga Mei 2017, diperoleh 124 responden. Hasil penelitian karakteristik sosiodemografi responden dapat dilihat pada Tabel 1-8.

Tabel 1. Distribusi frekuensi umur pasien HIV/AIDS

\begin{tabular}{ccc}
\hline $\begin{array}{c}\text { Umur } \\
\text { (tahun) }\end{array}$ & Jumlah & $\begin{array}{c}\text { Persentase } \\
\text { (\%) }\end{array}$ \\
\hline$<20$ & 7 & 5,65 \\
$20-29$ & 35 & 28,23 \\
$30-39$ & 50 & 40,32 \\
$40-49$ & 21 & 16,94 \\
$>50$ & 11 & 8,87 \\
Total & 124 & 100,00 \\
\hline
\end{tabular}

Dari hasil analisis distribusi frekuensi didapatkan jumlah pasien HIV/AIDS paling banyak pada kategori kisaran umur 30-39 tahun sebanyak 50 pasien dengan persentase $40,32 \%$. Infeksi HIV cenderung meningkat dan paling banyak terjadi pada kelompok usia produktif yaitu kelompok umur 2549 tahun dan umur 20-24 tahun (Ditjen P2P, 2016). Pada usia 30-39 tahun diasumsikan seseorang memiliki pekerjaan yang stabil secara finansial sehingga mampu memenuhi kebutuhan primer dan tersier seperti gaya hidup yang berisiko terinfeksi HIV. Orang dewasa cenderung memiliki perilaku berisiko, sedangkan usia 20-an cenderung kurang memahami adanya risiko penularan penyakit HIV/AIDS dari perilaku gaya hidup bebas sehingga mudah terjerumus seks tidak aman dan narkoba dengan jarum suntik tidak steril. Sekarang ini diperkirakan lebih dari 40 juta anak-anak dan orang dewasa terinfeksi HIV di seluruh dunia (Gallant, 2010).

Tabel 2. Distribusi frekuensi jenis kelamin

\begin{tabular}{lcc}
\hline Jenis Kelamin & Jumlah & $\begin{array}{c}\text { Persentase } \\
\text { (\%) }\end{array}$ \\
\hline Laki-laki & 92 & 74,19 \\
Perempuan & 32 & 25,81 \\
Total & 124 & 100,00 \\
\hline
\end{tabular}

Dari hasil analisis distribusi frekuensi jenis kelamin pasien HIV/AIDS, laki-laki lebih banyak dari pasien HIV/AIDS perempuan. Dari 124 pasien, sebanyak 92 pasien adalah laki-laki dengan persentase $74,19 \%$ dan pasien perempuan sebanyak 32 dengan persentase $25,81 \%$. Pada laki-laki kemungkinan terinfeksi HIV lebih besar karena beberapa laki-laki homoseksual yang berhubungan dengan seks dengan laki-laki secara anal (hubungan seks melalui anus) tanpa pengaman dapat menularkan kepada pasangan perempuannya. Laki-laki yang 
berhubungan dengan laki-laki, beberapa dari mereka juga berhubungan dengan perempuan secara tidak aman yang secara signifikan meningkatkan risiko penularan infeksi HIV (Friedman dkk., 2014).

Tabel 3. Distribusi frekuensi tingkat pendidikan

\begin{tabular}{lcc}
\hline $\begin{array}{l}\text { Tingkat } \\
\text { Pendidikan }\end{array}$ & Jumlah & $\begin{array}{c}\text { Persentase } \\
\text { (\%) }\end{array}$ \\
\hline Tidak Sekolah & 5 & 4,03 \\
SD & 5 & 4,03 \\
SMP & 4 & 3,23 \\
SMA & 63 & 50,81 \\
Perguruan Tinggi & 47 & 37,90 \\
Total & 124 & 100 \\
\hline
\end{tabular}

Dari hasil analisis distribusi frekuensi, didapatkan hasil tingkat pendidikan tertinggi adalah sekolah menengah atas, sejumlah 63 dengan persentase 50,81\%. Pendidikan di Indonesia bukan merupakan hal yang sulit. Adanya program wajib belajar 9 tahun, kemudian program belajar 12 tahun yang didukung sepenuhnya oleh pemerintah dengan program dana Bantuan Operasional Sekolah serta Kartu Jakarta Pintar membuat akses pendidikan hingga jenjang SMA sangat mudah didapatkan. Di Jakarta banyak sekolah negeri hingga swasta, di daerah Jakarta Utara ada 80 SMA/MA sederajat, sedangkan SMK ada 78 sekolah. Data dari dinas pendidikan Provinsi DKI Jakarta pada tahun 2015 ada sebanyak 9.836 siswa perempuan dan 11.990 siswa laki-laki di SMA serta 14.447 siswa perempuan dan 12.574 siswa laki-laki di SMK (Jakarta Open Data, 2015). Data dari BPS (2015), persentase penduduk menurut pendidikan yang ditamatkan tingkat SLTA hingga perguruan tinggi cukup banyak, yaitu sebesar $47,82 \%$.

Tabel 4. Distribusi frekuensi status

\begin{tabular}{lcc}
\multicolumn{2}{c}{ pekerjaan } \\
\hline $\begin{array}{l}\text { Status } \\
\text { Pekerjaan }\end{array}$ & Jumlah & $\begin{array}{c}\text { Persentase } \\
\text { (\%) }\end{array}$ \\
\hline Tidak Bekerja & 43 & 35 \\
Bekerja & 81 & 65 \\
Total & 124 & 100 \\
\hline
\end{tabular}

Dari hasil analisis didapatkan hasil status pekerjaan terbanyak adalah bekerja sebanyak 81 pasien dengan persentase $65,32 \%$ dan tidak bekerja sebanyak 43 pasien dengan persentase 34,68\%. Dari tingkat pendidikan diketahui bahwa tingkat pendidikan pasien HIV di RSPI. Prof. Dr. Sulianti Saroso adalah cukup tinggi sehingga banyak dari mereka yang memiliki pekerjaan. Dengan meningkatnya pendidikan seseorang akan semakin mudah dalam mendapatkan pekerjaan. 
Tabel 5. Distribusi frekuensi status pernikahan

\begin{tabular}{lcc}
\hline Status Pernikahan & Jumlah & $\begin{array}{c}\text { Persentase } \\
\text { (\%) }\end{array}$ \\
\hline Belum Menikah & 24 & $19 \%$ \\
Menikah & 94 & $76 \%$ \\
Cerai & 6 & $5 \%$ \\
Total & 124 & $100 \%$ \\
\hline
\end{tabular}

Dari hasil analisis didapatkan status pernikahan terbanyak adalah menikah sebanyak 94 pasien dengan persentase $75,81 \%$. Status menikah pada pasien memperbesar kemungkinan terjadinya risiko transmisi infeksi HIV melalui kontak seksual. Kemudian dari suatu pernikahan akan mendapatkan keturunan yang akan meningkatkan risiko infeksi HIV dari ibu ke anak.

Tabel 6. Distribusi frekuensi faktor risiko

\begin{tabular}{lcc}
\hline Faktor Risiko & Jumlah & $\begin{array}{c}\text { Persentase } \\
(\%)\end{array}$ \\
\hline Heteroseksual & 108 & 86,29 \\
Homoseksual & 6 & 4,84 \\
Biseksual & 2 & 1,61 \\
Perinatal & 2 & 1,61 \\
Transfusi & 2 & 1,61 \\
Penasun & 1 & 0,81 \\
Tidak Diketahui & 4 & 3,23 \\
Total & 124 & 100,00 \\
\hline
\end{tabular}

Dari hasil analisis distribusi frekuensi, didapatkan faktor risiko terbanyak adalah hubungan heteroseksual yaitu 108 pasien dengan persentase $86,29 \%$. Faktor risiko heteroseksual menunjukkan bahwa pola aktivitas seksual dari seorang pasien adalah berganti-ganti pasangan. Kebiasaan berganti-ganti pasangan inilah yang menjadi faktor risiko penularan infeksi HIV baik kepada pasangan resmi maupun tidak resmi. Kegiatan seksual berganti-ganti pasangan yang tidak diimbangi dengan kesadaran berperilaku seks secara aman menjadi faktor utama risiko penularan infeksi HIV, padahal penggunaan kondom sebagai pengaman merupakan tindakan pencegahan infeksi HIV yang sangat efektif (Laksana dan Lestari, 2010).

Anak-anak terinfeksi dari ibu yang terinfeksi HIV sewaktu hamil, persalinan, dan setelah melahirkan melalui pemberian ASI. Angka penularan selama kehamilan 5-10\%, sewaktu persalinan $10-20 \%$, dan saat pemberian ASI 10-20\%. Virus dapat ditemukan dalam ASI, sehingga ASI merupakan perantara penularan HIV dari ibu ke bayi yang seharusnya dapat dihindari (Noviana, 2016).

Infeksi HIV dapat terjadi pada individu yang menerima transfusi darah yang tercemar HIV. Diperkirakan 90$100 \%$ orang yang mendapat transfusi darah yang tercemar HIV akan 
terinfeksi. Transmisi juga terjadi pada individu pengguna narkotika intravena dengan pemakaian jarum suntik secara bergantian dalam satu kelompok tanpa menjaga sterilitasnya (Noviana, 2016).

Tabel 7. Distribusi frekuensi daerah tempat tinggal

\begin{tabular}{lcc}
\hline \multicolumn{1}{c}{ Daerah } & Jumlah & $\begin{array}{c}\text { Persentase } \\
\text { (\%) }\end{array}$ \\
\hline Sulawesi & 1 & 0,81 \\
Bogor & 2 & 1,61 \\
Tangerang & 3 & 2,42 \\
Sukabumi & 3 & 2,42 \\
Jakarta Timur & 3 & 2,42 \\
Tidak Lengkap & 5 & 4,03 \\
Jakarta Barat & 6 & 4,84 \\
Bekasi & 7 & 5,65 \\
Jakarta & 8 & 6,45 \\
Selatan & & \\
Jakarta Pusat & 25 & 20,16 \\
Jakarta Utara & 61 & 49,19 \\
Total & 124 & 100,00 \\
\hline
\end{tabular}

Hasil dari analisis data diketahui sejumlah pasien berasal dari berbagai daerah di Indonesia. Daerah terbanyak ada di Jakarta Utara sebanyak 61 orang dengan persentase 49,19\%. Jakarta Utara merupakan daerah paling banyak pasien HIV dikarenakan lokasi RSPI Prof. Dr. Sulianti Saroso yang berada di Jakarta Utara sehingga menjadi pusat kesehatan yang memiliki akses mudah dijangkau oleh pasien HIV. Di Jakarta Utara terkenal dengan tempat lokalisasi
Pekerja Seks Komersial (PSK) yang tersebar di berbagai wilayah Kecamatan Jakarta Utara, namun PSK yang paling banyak terjaring ada di sekitar terminal Tanjung Priok. Di Jakarta Utara terdapat sembilan lokasi prostitusi di antaranya Rawa Malang kolong jembatan, Menchos, Kecamatan Cilincing. Selain itu kafe-kafe di Lagoa, Kecamatan Koja, Pela-pela, Kafe-kafe di Taman BMW, Kecamatan Tanjung Priok, Gedong Panjang Rawabebek, Jembatan Gantung dan Kalijodo, Kecamatan Penjaringan (Poskotanews, 2014). Bahkan disebutkan oleh Vivanews (2015) Terminal Tanjung Priok merupakan pusat prostitusi di daerah Jakarta Utara. Dengan banyaknya PSK di daerah Jakarta Utara tentunya menambah data tingginya pasien infeksi menular seksual (IMS) dan HIV.

$$
\text { Secara demografi daerah }
$$

Jakarta Utara berbatasan langsung dengan Laut Jawa dimana terdapat pelabuhan Tanjung Priok sebagai pusat kegiatan perekonomian. Di daerah pelabuhan ada anak buah kapal (ABK) yang merupakan kelompok pria berisiko tinggi terinfeksi HIV akibat tingginya mobilitas dan jauh dari keluarga sehingga menimbulkan stres. Pada tahun 2015 terdapat 2400 ABK di 
seluruh Indonesia yang mengikuti Surveilans Terpadu Biologis dan Perilaku (STBP) oleh Kemenkes. ABK yang berperan dalam penularan HIV sebesar 0,82\% (STBP, 2015). Tidak terlalu banyak namun cukup signifikan mengingat $A B K$ tersebut jumlahnya ribuan.

Tabel 8. Distribusi frekuensi daerah tempat tinggal di Jakarta Utara

\begin{tabular}{lcc}
\hline Kecamatan & Jumlah & $\begin{array}{c}\text { Persentase } \\
\text { (\%) }\end{array}$ \\
\hline Cilincing & 6 & 9,84 \\
Koja & 11 & 18,03 \\
Kelapa Gading & 7 & 11,48 \\
Tanjung Priuk & 16 & 26,23 \\
Pademangan & 15 & 24,59 \\
Penjaringan & 6 & 9,84 \\
Total & 61 & 100,00 \\
\hline
\end{tabular}

Dari total 124 pasien, sebanyak

61 pasien diketahui tinggal di kecamatan yang berada di Jakarta Utara, dengan jumlah penderita HIV terbanyak adalah kecamatan Tanjung Priok sebanyak 16 orang dengan persentase 26,23\%. Tanjung Priuk merupakan kecamatan yang terdekat dengan RSPI Prof. Dr. Sulianti Saroso sehingga banyak pasien yang memilih berobat di pusat kesehatan terdekatnya. Di Tanjung Priok terdapat terminal yang terkenal dengan kegiatan prostitusinya dan berkumpulnya PSK, kemudian terdapat pelabuhan yang tinggi mobilisasi para $A B K$, juga supirsupir truk atau kontainer, mereka adalah kelompok pria berisiko tinggi. Berdasarkan STBP tahun 2011 diketahui sebesar 58\% ABK berhubungan dengan wanita pekerja seks dan sebesar $16 \%$ berhubungan dengan yang bukan pasangan tetapnya. Dari hubungan tersebut hanya $8 \%$ yang menggunakan kondom. Adanya penelitian tahun 2012 di pelabuhan Belawan, Medan menunjukkan banyaknya ABK yang tidak menyadari pentingnya seks aman, dengan persentase penggunaan kondom oleh ABK dengan PSK yang rendah sebesar 23,2\% (Sirait \& Sarumpaet, 2013). Mobilisasi yang tinggi turut pula dirasakan oleh supirsupir truk dan bis, mereka juga banyak menghabiskan waktu jauh dari keluarga dan pasangan mereka, sehingga mereka termasuk dalam pria berisiko tinggi dalam penularan HIV melalui kontak seksual yang tidak aman. Hasil penelitian karakteristik klinis responden dapat dilihat pada Tabel 9-12.

Dari total 124 pasien, hanya 113 pasien yang memiliki nilai tes CD4 awal, yang kemudian dianalisis dan didapatkan CD4 $\leq 200 \mathrm{sel} / \mu \mathrm{l}$ sebanyak 
67 pasien dengan persentase 59,29\%. CD4 adalah tipe limfosit khusus yang paling dipengaruhi HIV. Jumlah CD4 diukur biasanya tiga sampai enam bulan, baik saat terapi ARV maupun tidak. CD4 mengukur jumlah kerusakan yang dilakukan oleh HIV dan merupakan tes penting untuk memutuskan perlunya memulai terapi atau pencegahan pada IO (Gallant, 2010). Kasus di RSPI Prof. dr. Sulianti Saroso paling banyak adalah $\mathrm{CD} 4 \leq 200 \mathrm{sel} / \mu \mathrm{l}$ karena kebanyakan pasien akan berobat jika mereka merasa sakit, jadi banyak ditemukan nilai CD4 $\leq 200 \mathrm{sel} / \mu \mathrm{l}$. Disaat nilai CD4 rendah akan banyak sekali kemungkinan terjadi penyakit infeksi oportunistik.

Tabel 9. Distribusi frekuensi jumlah CD4

\begin{tabular}{lcc}
\hline CD4 & Jumlah & $\begin{array}{c}\text { Persentase } \\
\text { (\%) }\end{array}$ \\
\hline$\geq 500 \mathrm{sel} / \mu \mathrm{l}$ & 7 & 6,19 \\
$200-499 \mathrm{sel} / \mu \mathrm{l}$ & 39 & 34,51 \\
$\leq 200 \mathrm{sel} / \mu \mathrm{l}$ & 67 & 59,29 \\
Total & 113 & 100,00 \\
\hline
\end{tabular}

Tabel 10. Distribusi frekuensi stadium klinis HIV

\begin{tabular}{lcc}
\hline $\begin{array}{l}\text { Stadium } \\
\text { Klinis }\end{array}$ & Jumlah & $\begin{array}{c}\text { Persentase } \\
\text { (\%) }\end{array}$ \\
\hline Stadium I & 55 & 44,35 \\
Stadium II & 7 & 5,65 \\
Stadium III & 43 & 34,68 \\
Stadium IV & 19 & 15,32 \\
Total & 124 & 100,00 \\
\hline
\end{tabular}

Dari hasil analisis distribusi didapatkan hasil stadium । paling banyak yaitu 55 pasien dengan persentase $44,35 \%$. Penilaian stadium klinis harus dilakukan saat kunjungan awal dan setiap kali kunjungan untuk dapat menentukan terapi ARV dengan lebih tepat (Ditjen P2PL, 2011). Stadium I merupakan yang terbanyak dikarenakan jumlah pasien HIV yang mendapatkan terapi ARV tidak memandang dari stadium klinisnya tetapi dari nilai CD4 dan keadaan khusus, seperti pada ibu hamil yang terinfeksi HIV, berapapun stadium klinisnya harus diberikan terapi ARV untuk mencegah bayi ikut terinfeksi HIV dari ibu. Kemudian adanya tingkat kesadaran pasien HIV yang meningkat serta dari kesadaran faktor risiko HIV yang meningkat sehingga memulai terapi ARV sebagai pencegahan tingkatan stadium HIV menjadi AIDS.

Dari hasil analisis distribusi frekuensi, didapatkan 75 pasien tidak mengalami $10(60,48 \%)$, dan paling banyak 22 pasien mengalami kandidiasis $(17,74 \%)$. IO dapat menyertai penderita HIV dikarenakan keadaaan imun pasien menurun. IO adalah infeksi yang disebabkan organisme yang biasanya tetap 
terkendali karena kerja dari sistem kekebalan tubuh seluler yang mana pada ODHA sistem kekebalan tubuhnya dirusak oleh HIV. Gastro enteritis adalah penyebab diare pada ODHA yang berhubungan dengan infeksi. Gejalanya adalah diare, demam, mual, muntah, malaise, nyeri, dan kejang abdominal. Penyebabnya akibat rotavirus, adenovirus serotipe 40 dan 41, calicivirus, Norwalk-like virus, small round virus (SRV), astrovirus, coronavirus, dan torovirus. Sebagai pencegahan dapat dilakukan vaksinasi, menjaga pola hidup sehat, dan bersih dengan menjaga kebersihan peralatan makan, serta makanan yang dikonsumsi (Radji, 2010).

Tabel 11. Distribusi frekuensi infeksi oportunistik

\begin{tabular}{lcc}
\hline $\begin{array}{l}\text { Infeksi } \\
\text { Oportunistik }\end{array}$ & Jumlah & $\begin{array}{c}\text { Persentase } \\
\text { (\%) }\end{array}$ \\
\hline Gastro Enteritis & 1 & 0,81 \\
Hepatitis & 1 & 0,81 \\
Herpes Simpleks & 1 & 0,81 \\
Diare & 2 & 1,61 \\
Cryptosporidia & & \\
Tuberkulosis & 4 & 3,23 \\
Kombinasi & 7 & 5,65 \\
Toksoplasmosis & 11 & 8,87 \\
Kandidiasis & 22 & 17,74 \\
Tanpa IO & 75 & 60,48 \\
$\quad$ Total & 124 & 100,00 \\
\hline
\end{tabular}

Hepatitis merupakan infeksi sistemik pada hati yang berlangsung secara cepat setelah terjadi paparan virus. Gejala awalnya demam, malaise, anoreksia, mual, nyeri sendi dan otot, serta sakit kepala. Gejalanya berkembang menjadi fase ikterik dengan munculnya ikterus dan penurunan berat badan (Radji, 2010). Beberapa penelitian menunjukkan bahwa ODHA mungkin mengalami gejala hepatitis A dalam jangka waktu lebih lama, sehingga butuh waktu lebih lama untuk pulih total. Masalah lain yang harus dipertimbangkan ODHA dengan terapi ARV adalah dapat berdampak buruk untuk hati. Beberapa di antaranya dapat memperburuk gejala hepatitis A. Maka penggunaan semua ARV dihentikan dahulu sampai hepatitis A pulih atau tingkat enzim hati kembali normal (Green, 2016). Sebagai pencegahan vaksinasi dapat dilakukan segera saat nilai CD4 masih cukup tinggi.

Virus hepatitis B (HBV) dapat menular sama seperti HIV melalui hubungan seks dan Napza dengan suntik. Virus hepatitis B terdapat dalam darah, air mani, dan cairan vagina. Sama seperti hepatitis A, hepatitis B juga dapat dicegah dengan 
melakukan vaksinasi. Pada orang dengan koinfeksi HBV/HIV, ART harus dimulai segera tanpa memandang jumlah CD4 dan tanpa memandang tahapan penyakit hati (Green, 2016). ODHA yang memiliki penyakit dengan HBV atau HCV dalam jangka panjang akan menyebabkan kematian. Virus hepatitis dapat lebih cepat menyebabkan kerusakan hati pada penderita HIV dibandingkan dengan yang tidak terinfeksi HIV. ODHA dengan jumlah CD4 di bawah 200 berisiko paling tinggi terhadap kerusakan akibat HCV akibat rendahnya sistem kekebalan tubuh dalam melawan HCV. Sebanyak $80 \%$ penderita HIV yang menggunakan Napza jenis suntik juga terinfeksi virus hepatisis C. Bahaya koinfeksi HIV meningkat tiga kali lipat pada penyakit ginjal, gagal ginjal, dan menyebabkan kematian pada HIV. Sedangkan HCV belum ada vaksinasi yang dapat digunakan sebagai pencegahan penyakit (CDC, 2014).

Herpes simpleks terdapat dua tipe virus, yaitu HV-1 dan HSV-2 yang memiliki sifat hampir sama. Infeksi virus herpes mampu menginfeksi sel epitel mukosa atau sel limfosit. Kemudian menjalar dari sel perifer menuju sel saraf dan dapat bertahan selama bertahun-tahun sebelum teraktivasi kembali. Lesi kulit yang kemerahan berkembang menjadi macula yang mengeras dan membentuk papula. Cairan pada lesi penuh dengan virus yang infeksius. Pada ODHA, sel imunitasnya tidak dapat menghambat infeksi herpes sehingga herpes bersifat laten yang mudah kambuh (Radji, 2010). Diare Cryptosporidia disebabkan oleh infeksi parasit Cryptosporidium yang efeknya lebih besar pada pasien HIV. Gejalanya adalah diare terus menerus yang sangat mengganggu dan juga dapat menyebabkan kematian. Orang yang sangat beririko terinfeksi oleh parasit ini adalah homoseksual, orang yang dekat dengan orang terinfeksi, penjaga hewan, dan anak kecil. Pada orang sehat infeksinya akan sembuh dengan sendirinya, tapi dapat bertahan lebih dari satu bulan pada orang yang menderita imunitas rendah (Vyas, 2016).

Tuberkulosis merupakan penyakit infeksi kronis yang disebabkan oleh bakteri Mycobacterium tuberculosis yang biasanya menyerang paru namun dapat juga menyerang organ lain pada tubuh seperti tulang, ginjal, jantung, otak, dan lain 
sebagainya. Bakteri masuk melalui saluran pernafasan yang kemudian menyebar ke organ tubuh bagian lain. Tuberkulosis merupakan penyebab kematian pada pasien HIV sekitar 4050\%. Kematian akibat tidak terdiagnosis adanya tuberkulosis ekstra paru sehingga tidak adanya pengobatan yang diberikan pada pasien. Sekitar 60\% ODHA yang terinfeksi tuberkulosis akan sakit tuberkulosis aktif. Pasien HIV dengan tuberkulosis disebut koinfeksi TB-HIV. ODHA berisiko 10 kali lebih besar mengalami infeksi tuberkulois dibanding orang normal (Ditjen P2PL, 2012).

Toksoplasmosis disebabkan oleh infeksi dari parasit Toxoplasma gondii yang sering terdapat pada manusia dan hewan, diperkirakan sepertiga penduduk dunia mengalami infeksi ini. Infeksi pada manusia terjadi apabila menelan sesuatu yang terpapar parasit ini. Pada kehamilan yang terinfeksi toksoplasmosis dapat menyebabkan bayi lahir mati, kelainan SSP, hidrosefalus, dan keterbelakangan mental (Zaman, 1997).

Kandidiasis disebabkan oleh spesies jamur Candida albicans yang secara normal ditemukan di mulut, tenggorokan, usus, kulit, dan sering dijumpai di vagina pada perempuan. Infeksi terjadi akibat adanya pertumbuhan organisme yang berlebihan. Gejala yang timbul adalah edema, eritema, iritasi pada vulva dan vagina, serta pada pemeriksaan dalam akan ditemukan plak-plak putih yang pekat seperti keju. Pada laki-laki, gejala yang timbul adalah rasa gatal, panas, dan iritasi pada glans dan prepusium, serta nampak bercak-bercak putih menyerupai keju pada glans (Price dan Wilson, 2005).

Banyaknya pasien HIV dengan kandidiasis berhubungan dengan banyaknya nilai $C D 4 \leq 200 \mathrm{sel} / \mu \mathrm{l}$. Semakin rendah nilai CD4 pasien HIV maka semakin mudah terserang penyakit infeksi oportunistik. Hal ini diperkuat dengan penelitian yang dilakukan oleh Kusuma (2014) di RS Moewardi Surakarta bahwa ada hubungan yang signifikan antara rendahnya kadar CD4 dengan kejadian infeksi oportunistik kandidiasis.

Paling banyak ditemukan kombinasi 10 toksoplasmosis dengan tuberkulosis karena toksoplasmosis pada orang sehat dengan sistem imun yang baik, menyebabkan infeksi persisten kronis asimtomatik atau tanpa gejala. Tapi pada pasien dengan sistem 
imun rendah, ada reaktivasi parasit jika CD4 turun di bawah $200 \mathrm{sel} / \mu \mathrm{l}$ (Basavaraju, 2016). Toksoplasmosis termasuk dalam peringkat 10 besar penyakit oportunistik yang paling sering ditemukan pada pasien HIV terutama dengan nilai $C D 4<200$ sel/ $\mu$ l. Manusia dapat terinfeksi parasit ini dengan memakan daging mentah atau kurang matang yang mengandung kista jaringan, terpapar ookista pada tinja kucing, dan didapatkan melalui plasenta saat di dalam kandungan (Fitriana dan Pracoyo, 2017). Penurunan jumlah CD4 yang merupakan ciri utama HIV memberi sumbangan besar terhadap peningkatan risiko infeksi TB baik reaktivasi TB laten maupun bakteri TB yang baru. Pada orang normal, TB dapat menginfeksi, apalagi pada pasien HIV yang sistem imunnya menurun. Hal ini sesuai dengan responden terbanyak yang memiliki nilai CD4<200 sel/ $\mu \mathrm{l}$. Hasil penelitian karakteristik pola terapi responden dapat dilihat pada Tabel 1213.

Dari penggunaan terapi ARV pada pasien HIV yang ada di RSPI Prof. dr. Sulianti Saroso, sudah sesuai dengan pedoman nasional pengobatan antiretroviral yang dianjurkan. Paling banyak digunakan rejimen tenofovir + lamivudine + efavirenz (TDF + 3TC + EFV) dikarenakan hampir seluruh responden memiliki stadium klinis I yang cocok menggunakan rejimen lini I. Adapun penggunaan abacavir dikarenakan adanya perubahan terapi karena penggunaan zidovudine yang menyebabkan anemia, kemudian diganti dengan tenofovir, namun fungsi ginjalnya menurun.

Tabel 12. Distribusi frekuensi infeksi oportunistik kombinasi

\begin{tabular}{lcc}
\hline IO Kombinasi & Jumlah & $\begin{array}{c}\text { Persentase } \\
\text { (\%) }\end{array}$ \\
\hline $\begin{array}{l}\text { Toksoplasmosis+ } \\
\text { Tuberkulosis }\end{array}$ & 3 & 42,86 \\
$\begin{array}{l}\text { Toksoplasmosis+ } \\
\text { Limfodenopati }\end{array}$ & 1 & 14,29 \\
$\begin{array}{l}\text { Toksoplasmosis+ } \\
\text { Kandidiasis+ }\end{array}$ & 1 & 14,29 \\
$\begin{array}{l}\text { Tuberkulosis } \\
\text { Kandidiasis+ }\end{array}$ & 1 & 14,29 \\
$\begin{array}{l}\text { Tuberkulosis } \\
\text { Tuberkulosis+ } \\
\text { Penicilliosis }+\end{array}$ & 1 & 14,29 \\
$\begin{array}{l}\text { Pneumocystis } \\
\text { Pneumonia } \\
\text { Total }\end{array}$ & 1 & 100,00 \\
\hline
\end{tabular}

Mekanisme kerja obat terapi ARV golongan NRTI menghambat enzim DNA polymerase dependen RNA HIV (reverse transcriptase) HIV sehingga pertumbuhan rantai DNA dan replikasi HIV terhenti. Contoh NRTI yaitu zidovudin, didanosin, lamivudine, abacavir. Mekanisme kerja obat terapi ARV golongan NNRTI menghambat transkripsi RNA HIV-1 menjadi DNA, 
suatu langkah penting dalam proses replikasi virus. Obat golongan ini menurunkan jumlah HIV dalam darah (viral load) dan meningkatkan CD4, contohnya nevirapin, delavirdin, efavirenz. Mekanisme kerja obat terapi ARV golongan PI menghambat aktivitas protease HIV dan mencegah pemutusan poliprotein HIV yang berfungsi untuk pematangan virus HIV (Price dan Wilson, 2005).

Tabel 13. Distribusi frekuensi jenis terapi ARV

\begin{tabular}{lcc}
\hline Rejimen & Jumlah & $\begin{array}{c}\text { Persentase } \\
\text { (\%) }\end{array}$ \\
\hline $\begin{array}{l}\text { Zidovudine+ } \\
\text { Lamivudine+ } \\
\text { Nevirapine } \\
\text { (ZDV+3TC+NVP) }\end{array}$ & 29 & 23,39 \\
Zidovudine+Lami \\
vudin+Efavirenz & 8 & 6,45 \\
(ZDV+3TC+EFV) & & \\
Tenofovir+ & & \\
Lamivudine+ & 3 & 2,42 \\
Nevirapine & & \\
(TDF+3TC+NVP) & & \\
Tenofovir+ & & \\
Lamivudine+ & 66 & 53,23 \\
Efavirenz & & \\
(TDF+3TC+EFV) & & \\
Tenofovir+ \\
Emtricitabine+
\end{tabular}

Tabel 14. Distribusi frekuensi kepatuhan terapi ARV

\begin{tabular}{lcc}
\hline Kepatuhan & Jumlah & $\begin{array}{c}\text { Persentase } \\
(\%)\end{array}$ \\
\hline Patuh & 93 & 75,00 \\
Tidak Patuh & 31 & 25,00 \\
Total & 124 & 100,00 \\
\hline
\end{tabular}

Dari hasil analisis distribusi didapatkan 93 pasien patuh pada terapi ARV dengan persentase 75\%, dan 31 pasien tidak patuh pada terapi ARV dengan persentase 25\%. Adanya ketidakpatuhan terapi ARV dapat dikarenakan berbagai faktor yang terjadi pada pasien HIV. Misalnya adanya efek samping obat ARV, kombinasi obat ARV yang terlalu banyak, tidak adanya kesadaran untuk sehat, serta tidak memiliki motivasi dalam melakukan terapi ARV. Hal tersebut yang akan menjadi perhatian bagi para dokter, konselor, dan pengawas minum obat sehingga didapatkan tingkat kepatuhan yang baik. Ketidakpatuhan terapi ARV menyebabkan munculnya infeksi oportunistik akibat laju stadium klinis HIV yang berkaitan dengan jumlah CD4 darah yang terus menurun akibat infeksi HIV yang tidak diterapi. Nilai kepatuhan didapatkan dengan menghitung jumlah sisa obat dibagi dengan jumlah obat yang seharusnya diminum kemudian 
dikali seratus persen. Dari persen yang didapat apabila $>95 \%$ penilaiannya adalah 1 yang artinya lebih dari 3 dosis lupa diminum dalam 30 hari, 8095\% penilaiannya adalah 2 yang artinya 3- 12 dosis lupa diminum dalam 30 hari, $<80 \%$ penilaiannya adalah 3 yang artinya lebih dari 12 dosis obat lupa diminum dalam 30 hari. Penilaian ini diasumsikan obat yang dikonsumsi adalah dosis 2 kali sehari, namun jika paduan ART yang diberikan terdiri dari berbagai dosis maka dipilih adherens obat yang paling jelek.

Kepatuhan diperlukan untuk mendapatkan keberhasilan terapi dan mencegah resistensi terjadi. Untuk mendapatkan respon penekanan jumlah virus sebesar $85 \%$ diperlukan kepatuhan penggunaan obat $90-95 \%$. Monitoring kepatuhan dapat dilakukan dengan menghitung jumlah obat yang tersisa saat pasien mengambil obat kembali, membuat kartu monitoring penggunaan obat, melakukan wawancara dengan pengawas minum obat (Ditjen Binfar, 2006).

\section{Kesimpulan}

$$
\begin{aligned}
& \text { Karakteristik sosiodemografi } \\
& \text { pasien HIV/AIDS di RSPI Prof. dr. } \\
& \text { Sulianti Saroso tahun } 2016 \text { paling }
\end{aligned}
$$

banyak adalah usia dewasa 30-39 tahun sebesar $40,32 \%$ yang didominasi oleh laki-laki sebesar 74,19\%. Tingkat pendidikan terbanyak adalah SMA sebesar 50,81\% dan lebih dari setengahnya atau $65 \%$ memiliki pekerjaan serta berstatus telah menikah sebesar $76 \%$. Faktor risiko terbanyak adalah heteroseksual sebesar 86,29\%, dan daerah tinggal paling banyak di Jakarta Utara sebesar 49,19\% dan Kecamatan Tanjung Priuk sebesar $26,23 \%$.

Karakteristik klinis pasien HIV/AIDS di RSPI Prof. dr. Sulianti Saroso periode Januari- Juni 2016 yang paling banyak adalah jumlah CD4 di bawah $200 \mathrm{sel} / \mu \mathrm{l}$ sebesar 59,29\% dengan stadium I sebesar 44,35\%. Jumlah paling banyak tanpa mengalami infeksi oportunistik sebesar 60,48\% dengan kandidiasis $17,74 \%$ merupakan kasus yang banyak terjadi, serta kombinasi infeksi oportunistik terbanyak adalah toksoplasmosis + tuberkulosis sebesar $42,86 \%$.

\section{Daftar Pustaka}

Basavaraju, A. 2016. Toxoplasmosis in HIV infection: an overview. Trop Parasitol, 6(2):129-135. 
BPS. 2015. Badan Pusat Stastistik Jakarta Utara: sosial dan kependudukan.

https://jakutkota.bps.go.id/index. php. Diakses tanggal 12 September 2017.

CDC, Centers for Disease Control and Prevention. 2014. HIV and viral hepatitis. https://www.cdc.gov/hiv/pdf/li brary_factsheets_HIV_and_viral _Hepatitis.pdf. Diakses tanggal 24 Juli 2017.

Ditjen Binfar. 2006. Pedoman Pelayanan Kefarmasian untuk Orang dengan HIV/AIDS (ODHA). Jakarta: Departemen Kesehatan Republik Indonesia.

Ditjen P2P. 2016. Laporan Situasi Perkembangan HIV/AIDS di Indonesia April-Juni 2016. Jakarta: Kementrian Kesehatan Republik Indonesia.

Ditjen P2P. 2016. Situasi Penyakit HIV AIDS di Indonesia 1 Desember 2016. Jakarta: Kementrian Kesehatan Republik Indonesia.

Ditjen P2PL. 2011. Pedoman Nasional Tatalaksana Klinis Infeksi HIV dan Terapi Antiretroviral pada Orang Dewasa. Jakarta: Kementrian Kesehatan Republik Indonesia.

Ditjen P2PL. 2012. Petunjuk Teknis Tata Laksana Klinis Ko-infeksi TB-HIV. Jakarta: Kementrian Kesehatan Republik Indonesia.

Fajrin, P.N. 2012. Evaluasi terapi ARV terhadap perubahan jumlah CD4 dan berat badan dan terapi OAT terhadap perubahan berat badan pada pasien koinfeksi TB/HIV di Unit Pelayanan Terpadu HIV RSUPN dr. Cipto Mangunkusumo tahun 2009. Skripsi. Program Studi Kesehatan Masyarakat, Fakultas Kesehatan Masyarakat, Universitas Indonesia.

Fitriana dan Pracoyo, N.E. 2017. Deteksi Toxoplasma gondii dari spesimen urine penderita HIV/AIDS. Media Litbangkes, 27(2):105-110.

Friedman, M.R., Wei, C., Klem, M.L., Silvestre, A.J., Markovic, N., Stall, R. 2014. HIV infection and sexual risk among men who have sex with men and women (WSMW): a systematic review and metaanalysis. Plos ONE, 9(1):e87139.

Gallant, J. 2010. 1000 Tanya-Jawab Mengenai HIV dan AIDS. Jakarta: PT Indeks.

Green, C.W. 2016. Hepatitis dan Virus HIV: Seri Buku Kecil HIV-AIDS. Jakarta: Yayasan Spiritia.

Jakarta Open Data. 2015. Dataset jumlah sekolah, guru, murid, dan ruang kelas pada sekolah menengah atas menurut status sekolah dan kabupaten kota administrasi di Provinsi DKI Jakarta pada tahun 2015. http://data.jakarta.go.id/dataset/ jumlahsekolah-guru-muriddanruangkelassmamenurutstatus sekolahdkijakarta/resource/b01f6 863-92af-477d-8879-

3671a32e79f4. Diakses tanggal 12 September 2017.

Kunoll. 2013. Pengantar Epidemiologi Penyakit Menular: untuk Mahasiswa Kesehatan 
Masyarakat. Jakarta: Trans Info Media.

Kusuma, L.A. 2014. Hubungan kadar CD4 dengan kejadian kandidiasis oral pada penderita HIV/AIDS di RSUD Moewardi Surakarta. Skripsi. Fakultas Kedokteran, Universitas Muhammadiyah Surakarta.

Laksana, A.S.D., Lestari, D.W.D. 2010. Faktor-faktor risiko penularan HIV/AIDS pada laki-laki dengan orientasi seks heteroseksual dan homoseksual di Purwokerto. Mandala of Health, 4(2):113-123.

Lubis, Z.D. 2011. Gambaran karakteristik individu dan faktor risiko terhadap terjadinya infeksi oportunistik pada penderita HIV/AIDS di Rumah Sakit Penyakit Infeksi Sulianti Saroso tahun 2011. Skripsi. Program Sarjana Kesehatan Masyarakat, Fakultas Kesehatan Masyarakat, Universitas Indonesia.

Najmah. 2016. Epidemiologi Penyakit Menular. Jakarta: Trans Info Media.

Noviana, N. 2016. Konsep HIV/AIDS Seksualitas \& Kesehatan Reproduksi. Jakarta: Trans Info Media.

Poskotanews. 2014. Rentan penularan penyakit HIV/AIDS Jakarta Utara dikepung tempat pelacuran liar. http://poskotanews.com/2014/1 1/29/jakarta-utara-dikepung- tempat-pelacuran-liar/. Diakses tanggal 12 September 2017.

Price, S.A. dan Wilson, L.M. 2005. Patofisiologi: Konsep Klinis Proses-Proses Penyakit. Edisi 6. Vol 1. Jakarta: Penerbit Buku Kedokteran EGC.

Radji, M. 2010. Imunologi dan Virologi. Cetakan Pertama. Jakarta: PT ISFI Penerbitan.

Sirait, L.M. dan Sarumpaet, S. 2013. Hubungan komponen health belief model (HBM) dengan penggunaan kondom pada anak buah kapal (ABK) di Pelabuhan Belawan. Jurnal Pre Cure, 1:4349.

STBP. 2015. Survei Terpadu Biologis dan Perilaku Tahun 2015. Jakarta: Kementrian Kesehatan Republik Indonesia.

Vivanews. 2015. Terminal Tanjung Priok, pusat prostitusi di Jakarta Utara.

http://www.viva.co.id/berita/met ro/686747-terminal-tanjungpriok-pusatprostitusi-di-jakartautara. Diakses tanggal 12 September 2017.

Vyas, J.M. 2016. Cryptosporidium enteritis. https:// medlineplus.gov/ency/article/000 617.htm. Diakses tanggal 24 Juli 2017.

Zaman, V. 1997. Atlas Parasitologi Kedokteran. Jakarta: Hipokrates. 